\title{
Assessing the Effects of Grass Carp Excretion and Herbivory of Submerged Macrophytes on Water Quality and Zooplankton Communities
}

\author{
Jian Sun ${ }^{1,2}$, Lin Ma ${ }^{1}$, Long Wang ${ }^{1,2}$, Yun $\mathrm{Hu}^{1,2}$, \\ Yi Zhang ${ }^{1}$, Zhenbin Wu ${ }^{1}$, Feng $\mathrm{He}^{1 *}$ \\ ${ }^{1}$ State Key Laboratory of Freshwater Ecology and Biotechnology, Institute of Hydrobiology, \\ Chinese Academy of Sciences, Wuhan 430072, China \\ ${ }^{2}$ University of Chinese Academy of Sciences, Beijing 100049, China
}

Received: 26 October 2016

Accepted: 7 February 2017

\begin{abstract}
Grass carp (Ctenopharyngodon idella) play an important role in the ecological restoration of water bodies, and it is crucial to understand the mechanism behind this. An experiment was performed in tanks consisting of three treatments: 1) without fish (control treatment, CON), 2) with fish unable to feed on submerged macrophytes (excretion treatment, EXCR), and 3) with fish swimming free (herbivory plus excretion treatment, HERB-EXCR). Treatments were conducted with varying macrophytic compositions (Vallisneria natans (Lour.) Hara, Ceratophyllum demersum L., and both species) and carp densities (low, medium, and high: $0.15,0.30$, and $0.45 \mathrm{~g} \cdot \mathrm{L}^{-1}$ respectively, in EXCR and HERB-EXCR). Results indicated that in EXCR and HERB-EXCR, water quality was better with a lower density of grass carp. In EXCR, the water quality in tanks with V. natans was worse than in other tanks, and water quality in C. demersum tanks was better under the HERB-EXCR treament. Compared to EXCR, grass carp in HERB-EXCR significantly increased concentrations of $\mathrm{NH}_{4}^{+}-\mathrm{N}, \mathrm{NO}_{2}^{-}-\mathrm{N}$, and chlorophyll a. The effects on biomasses of protozoa, copepods, and total zooplankton in HERB-EXCR were greater than in the other treatments. Integrated analysis showed that grass carp herbivory on submerged macrophytes could be the central mechanism accounting for the changes in water quality and zooplankton communities.
\end{abstract}

Keywords: grass carp, excretion and herbivory, submerged macrophytes, water quality, zooplankton communities

*e-mail: hefeng@ihb.ac.cn 


\section{Introduction}

Submerged macrophytes, which are the main aquatic primary producers, act as indicators of the ecological quality of freshwater ecosystems because they can improve water transparency, purify water quality, and maintain water biodiversity [1-2].

However, as exceptional growth in submerged plants can cause serious problems for many water use activities, humans have utilized grass carp (Ctenopharyngodon idella) as an attractive mechanism to control plant growth [3-4]. Aquatic macrophytes become very rare in Waikato drainage systems two months after the introduction of grass carp [5]. However, the results brought about by grass carp differ according to different stocking densities. Zajicek et al. (2009) found that in order to obtain hydrilla management objectives, an appropriate option was stocking low levels of grass carp [6]. Richardson (2008) studied that with a stocking density of approximately 20 to 30 grass carp per vegetated hectare, hydrilla coverge was reduced by $97 \%$ in three years [7]. With grass carp density increasing, aquatic plant abundance declined and was eliminated at high densities [8]. Garner (2013) detected that grass carp at high-density stocking of 100 fish per vegetated hectare can control Myriophyllum aquaticum invasive aquatic plants not even preferred by grass carp [9]. And Grass carp can eliminate hornwort over summer when stocked at high density $(>1000$ grass carp per vegetated hectare) [10].

Nonetheless, there is a controversy regarding the reduction in growth of submerged plants by using grass carp because it is difficult to predict the impacts on water quality and aquatic ecosystems of grass carp feeding on submerged macrophytes. Many studies on the effects of fish introduction in lakes concern the use of other species of fish [11-13]. For example, after stocking filter-feeding fish in the reservoir, the effects on the biomass of total zooplankton and total phytoplankton were significant [14], and lake Apopka including high densities of gizzard shad and threadfin shad, has a lower biomass ratio of zooplankton to phytoplankton (BZ:BP) [15]. In aspect to assessing the changes in water ecosystems caused by grass carp, however, although Krupska et al. (2012) investigated the influences on vegetation and charophytes of stocking grass carp in lakes [16], research about the effects of grass carp on water quality and zooplankton communities are relatively few. Hence, it is important to elucidate the effects on water quality and zooplankton communities of grass carp feeding on submerged macrophytes. Moreover, we aim to better understand the different effects of grass carp excretion and herbivory by comparing the results of two treatment groups.

Therefore, this study was carried out with three stocking rates and three type combinations of submerged vegetations to accurately evaluate and contrast the impacts of excrement from and herbivory by grass carp on water quality and zooplankton. The purposes of this study were to: 1) investigate and compare the effects of excrement from and herbivory by grass carp on water quality and 2) investigate the effects of grass carp on the zooplankton community structure.

\section{Material and Methods}

\section{Experimental Materials}

We conducted the experiments in round tanks (upper diameter $65 \mathrm{~cm}$, base diameter $40 \mathrm{~cm}$, depth $70 \mathrm{~cm}$, volume $\sim 200 \mathrm{~L}$ ). Tanks were filled with water that had been aerated for 24 hours before the experiment. Water quality parameters are shown in Table 1. Sediment collected from a natural pond $\left(30^{\circ} 20^{\prime} \mathrm{N}, 120^{\circ} 15^{\prime} \mathrm{E}\right)$ was added to the bottom of each tank, to a depth of $5 \mathrm{~cm}$. Sediment compositions (mean \pm SD) were: total nitrogen $(\mathrm{TN})=1.83 \pm 0.04 \mathrm{mg} \cdot \mathrm{g}^{-1}$, total phosphorus $(\mathrm{TP})=1.49 \pm 0.14 \mathrm{mg} \cdot \mathrm{g}^{-1}$, and organic matter $(\mathrm{OM})$ $=3.60 \pm 0.22 \%$. Dinas (depth of $3 \mathrm{~cm}$ ) was put on the sediment to prevent sediment resuspension. Grass carp were obtained from Linghu Fishery (Huzhou, Zhejiang Province, China) and reared in a $5 \times 3 \times 2 \mathrm{~m}$ fish cage in a natural pond $\left(30^{\circ} 20^{\prime} \mathrm{N}, 120^{\circ} 15^{\prime} \mathrm{E}\right)$. Fish (mean \pm SD, weight $30 \pm 1 \mathrm{~g}$, total length $19.5 \pm 0.5 \mathrm{~cm}$ ) were randomly collected from the fish cage and acclimated to the experimental conditions for one week. Submerged marcrophytes (Vallisneria natans (Lour.) Hara and Ceratophyllum demersum L.) were collected from two sites in the Maojiabu sublake of West Lake $\left(30^{\circ} 14^{\prime} \mathrm{N}\right.$, $120^{\circ} 7^{\prime}$ E, Hangzhou, Zhejiang Province, China; Fig. 1).

\section{Experimental Design}

We used three treatments: 1) macrophytes without fish (control treatment, CON); 2) macrophytes and fish, with a

Table 1. Mean values \pm SD for the characteristics of experimental water at the beginning in EXCR and HERB- EXCR.

\begin{tabular}{|c|c|c|c|c|c|}
\hline Parameters & $\mathrm{TN}\left(\mathrm{mg} \cdot \mathrm{L}^{-1}\right)$ & $\mathrm{TP}\left(\mathrm{mg} \cdot \mathrm{L}^{-1}\right)$ & $\mathrm{NH}_{4}^{+}-\mathrm{N}\left(\mathrm{mg} \cdot \mathrm{L}^{-1}\right)$ & $\mathrm{NO}_{2}^{-}-\mathrm{N}\left(\mathrm{mg} \cdot \mathrm{L}^{-1}\right)$ & $\mathrm{Chl} \mathrm{a}\left(\mu \mathrm{g} \cdot \mathrm{L}^{-1}\right)$ \\
\hline $\begin{array}{c}\mathrm{EXCR} \\
\text { and CON }(\mathrm{E})\end{array}$ & $3.890 \pm 0.110$ & $0.048 \pm 0.003$ & $0.197 \pm 0.054$ & $0.018 \pm 0.002$ & $0.060 \pm 0.008$ \\
\hline $\begin{array}{c}\text { HERB-EXCR } \\
\text { and CON (HE) }\end{array}$ & $1.117 \pm 0.016$ & $0.069 \pm 0.006$ & $0.073 \pm 0.038$ & $(0.075 \pm 0.021)^{*} 10^{-2}$ & $0.869 \pm 0.001$ \\
\hline
\end{tabular}

Notes: EXCR and HERB-EXCR represent excretion treatment and herbivory plus excretion treatment, respectively. CON (E) and CON (HE) are the control treatments for excretion treatment and herbivory plus excretion treatment, respectively. Concentrations of total nitrogen, total phosphorus and chlorophyll a are abbreviated as TN, TP and chl a respectively. 


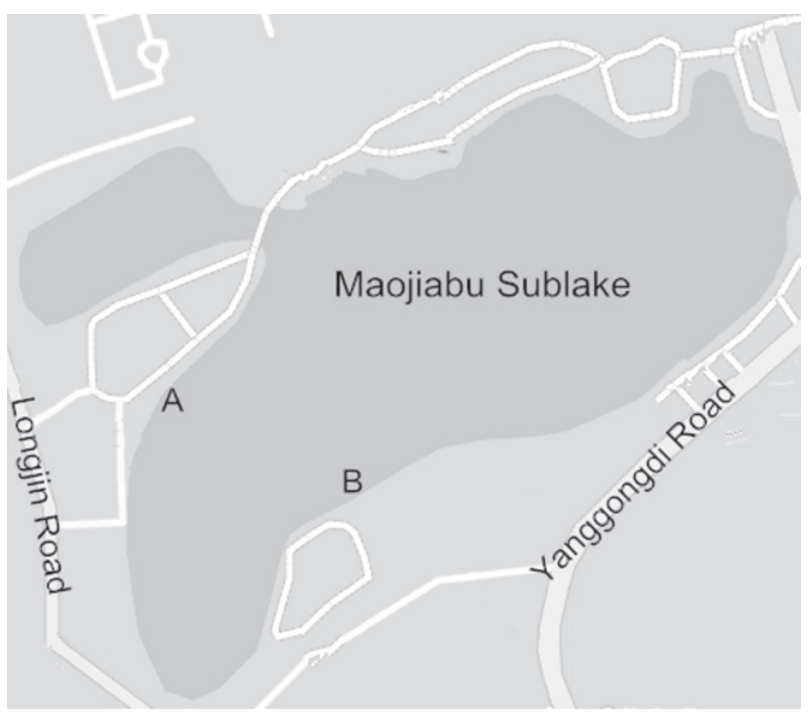

Fig. 1. Location of two sites of submerged marcrophytes (A and B) in West Lake, China.

net barrier (mesh size $1 \mathrm{~cm}$ ) $25 \mathrm{~cm}$ below the water surface to prevent fish herbivory on macrophytes, but fish excretions were still able to reach the macrophytes (excretion treatment, EXCR); and 3) macrophytes and fish without any barrier, exposing the macrophytes to both herbivory and excretion (herbivory plus excretion treatment, HERBEXCR) (Fig. 2). Treatments were conducted with varying macrophytic compositions ( $V$. natans, $C$. demersum, and both species) and carp densities (low, medium, and high: $0.15,0.30$, and $0.45 \mathrm{~g} \cdot \mathrm{L}^{-1}$, respectively, in EXCR and HERB-EXCR) (Table 2). Grass carp were fed with fresh $V$. natans or $C$. demersum daily to avoid starvation, and uneaten plants were replaced by fresh ones the following day in EXCR that lasted 35 days. Fish that consumed the plants present in HERB-EXCR lasted 28 days.

\section{Sampling and Analysis}

Water in the tanks was sampled once a week between 11:00 and 12:00 after the introduction of grass carp. $\mathrm{TN}, \mathrm{TP}, \mathrm{NH}_{4}^{+}-\mathrm{N}$, and $\mathrm{NO}_{2}^{-}-\mathrm{N}$ were analyzed according to standard procedures [17]. Chlorophyll a ( chl a) was measured using Whatman GF/C glass filters $(0.45 \mathrm{~mm})$

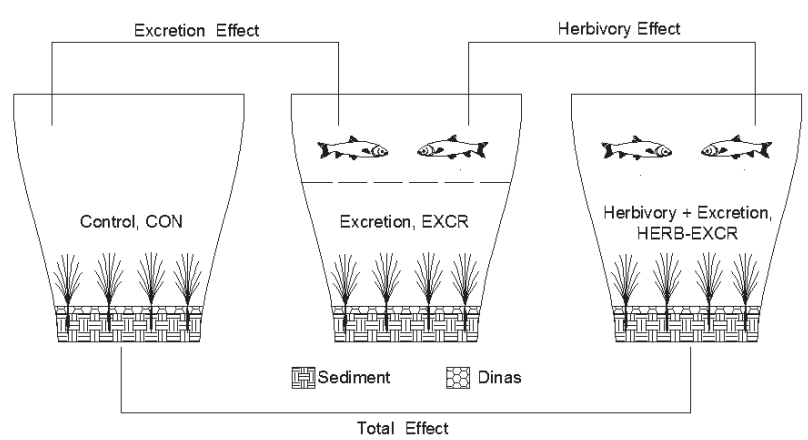

Fig. 2. Schematic graph of the experimental design.
Table 2. Experimental design of the three treatments with grass carp (Ctenopharyngodon idellus) and two macrophyte species (Vallisneria natans and Ceratophyllum demersum).

\begin{tabular}{|c|c|c|c|c|}
\hline & \multirow{2}{*}{$\begin{array}{c}\text { Density } \\
\text { of grass } \\
\text { carp } \\
\left(\mathrm{g} \cdot \mathrm{L}^{-1}\right)\end{array}$} & \multicolumn{2}{|c|}{$\begin{array}{l}\text { Density of macrophyte } \\
\qquad\left(\mathrm{g} \cdot \mathrm{m}^{-2}\right)\end{array}$} \\
\hline & & & V. natans & C. demersum \\
\hline \multirow[t]{3}{*}{ No carp } & $0-\mathrm{V}$ & \multirow{3}{*}{0} & 478 & 0 \\
\hline & $0-\mathrm{VC}$ & & 239 & 239 \\
\hline & $0-\mathrm{C}$ & & 0 & 478 \\
\hline \multirow{3}{*}{$\begin{array}{l}\text { Low } \\
\text { density }\end{array}$} & L-V & \multirow{3}{*}{0.15} & 478 & 0 \\
\hline & $\mathrm{L}-\mathrm{VC}$ & & 239 & 239 \\
\hline & $\mathrm{L}-\mathrm{C}$ & & 0 & 478 \\
\hline \multirow{3}{*}{$\begin{array}{l}\text { Medium } \\
\text { density }\end{array}$} & $\mathrm{M}-\mathrm{V}$ & \multirow{3}{*}{0.30} & 478 & 0 \\
\hline & $\mathrm{M}-\mathrm{VC}$ & & 239 & 239 \\
\hline & $\mathrm{M}-\mathrm{C}$ & & 0 & 478 \\
\hline \multirow{3}{*}{$\begin{array}{l}\text { High } \\
\text { desnity }\end{array}$} & $\mathrm{H}-\mathrm{V}$ & \multirow{3}{*}{0.45} & 478 & 0 \\
\hline & $\mathrm{H}-\mathrm{VC}$ & & 239 & 239 \\
\hline & $\mathrm{H}-\mathrm{C}$ & & 0 & 478 \\
\hline
\end{tabular}

Notes: the per square meter of $\mathrm{g} \cdot \mathrm{m}^{-2}$ is the bottom surface of the tank.

to first filter water samples, and then filters were extracted with $90 \%$ acetone for 24 hours.

\section{Zooplankton Community Analysis}

Samples of zooplankton were obtained from each tank by filtering $10.0 \mathrm{~L}$ water with a zooplankton net made of standard bolting silk cloth (No. 100) at the initiation and termination of the experiment. The zooplankton samples were then concentrated to $30 \mathrm{~cm}^{3}$, preserved in $5 \%$ methanal, and counted under a stereoscopic microcope using a Sedgwick-Rafter cell count [18]. For each zooplankton sample we studied the biomasses of protozoa, rotifers, cladocerans, copepods, and total zooplankton.

\section{Data Analysis}

One-way ANOVA was used to test differences in biological parameters $\mathrm{TN}, \mathrm{TP}, \mathrm{NH}_{4}^{+}-\mathrm{N}, \mathrm{NO}_{2}^{-}-\mathrm{N}$, and chl a among the three treatments. A Tukey test was performed for multiple comparison of means. SPSS 13.0 for Windows (SPSS Inc., Chicago, IL, USA) was applied for these analyses and $\mathrm{p}<0.05$ indicated a significant difference.

In order to account for time effects and better compare the water quality in EXCR and HERB-EXCR, we calculated time-weighted average (WA) and increasing rates (IR) of five variables in each tank using the following formulae:

$W A=\left[\left(1 \times V_{1}\right)+\left(2 \times V_{2}\right)+\ldots+\left(n \times V_{\mathrm{n}}\right)\right] /(1+2+\ldots+n)$ 


$$
\mathrm{IR}=(\mathrm{WA}-\mathrm{C}) / \mathrm{C}^{*} 100
$$

...where $\mathrm{V}$ is a variable of TN, TP, $\mathrm{NH}_{4}^{+}-\mathrm{N}, \mathrm{NO}_{2}^{-}-\mathrm{N}$ and chl a at each sampling date [20-21]; and $\mathrm{C}$ is the value of $\mathrm{TN}, \mathrm{TP}, \mathrm{NH}_{4}^{+}-\mathrm{N}, \mathrm{NO}_{2}^{-}-\mathrm{N}$ and chl a as listed in Table 1.

To assess the effect of fish excretion on zooplankton, we used effect size $(E S)=\left[\ln \left(N_{t, E} / N_{0, E}\right)-\ln \left(N_{t, C} / N_{0, C}\right)\right]$ [22] as the difference between EXCR and CON. Similarly, $(E S)=\left[\ln \left(N_{t, H E} / N_{0, \mathrm{HE}}\right)-\ln \left(N_{t, C} / N_{0, C}\right)\right]$ was utilized to assess the total effect of fish on zooplankton as the difference between HERB-EXCR and CON. $\mathrm{N}_{\mathrm{t}, \mathrm{E}}, \mathrm{N}_{\mathrm{t}, \mathrm{C}}$, and $\mathrm{N}_{\mathrm{t}, \mathrm{HE}}$ (or $\mathrm{N}_{0, \mathrm{E}}, \mathrm{N}_{0, \mathrm{C}}$, and $\mathrm{N}_{0, \mathrm{HE}}$ ) denote the biomasses of zooplankton in EXCR, CON, and HERB-EXCR after time $t$ (or $t=0)$ of the experiment, respectively. When $\mathrm{ES} \neq 0$, there was a significant difference between EXCR and CON or HERB-EXCR and CON, indicating that the effect of fish excretion on zooplankton and the total effect (excretion and herbivory) of fish on zooplankton was significantly different from zero.

\section{Results}

\section{Effects of Grass Carp on Water Quality \\ Effects of Excretion on Water Quality}

During 35 days of treatments, changes in water quality caused by excretion from grass carp are shown in Figs 3 and 4 .

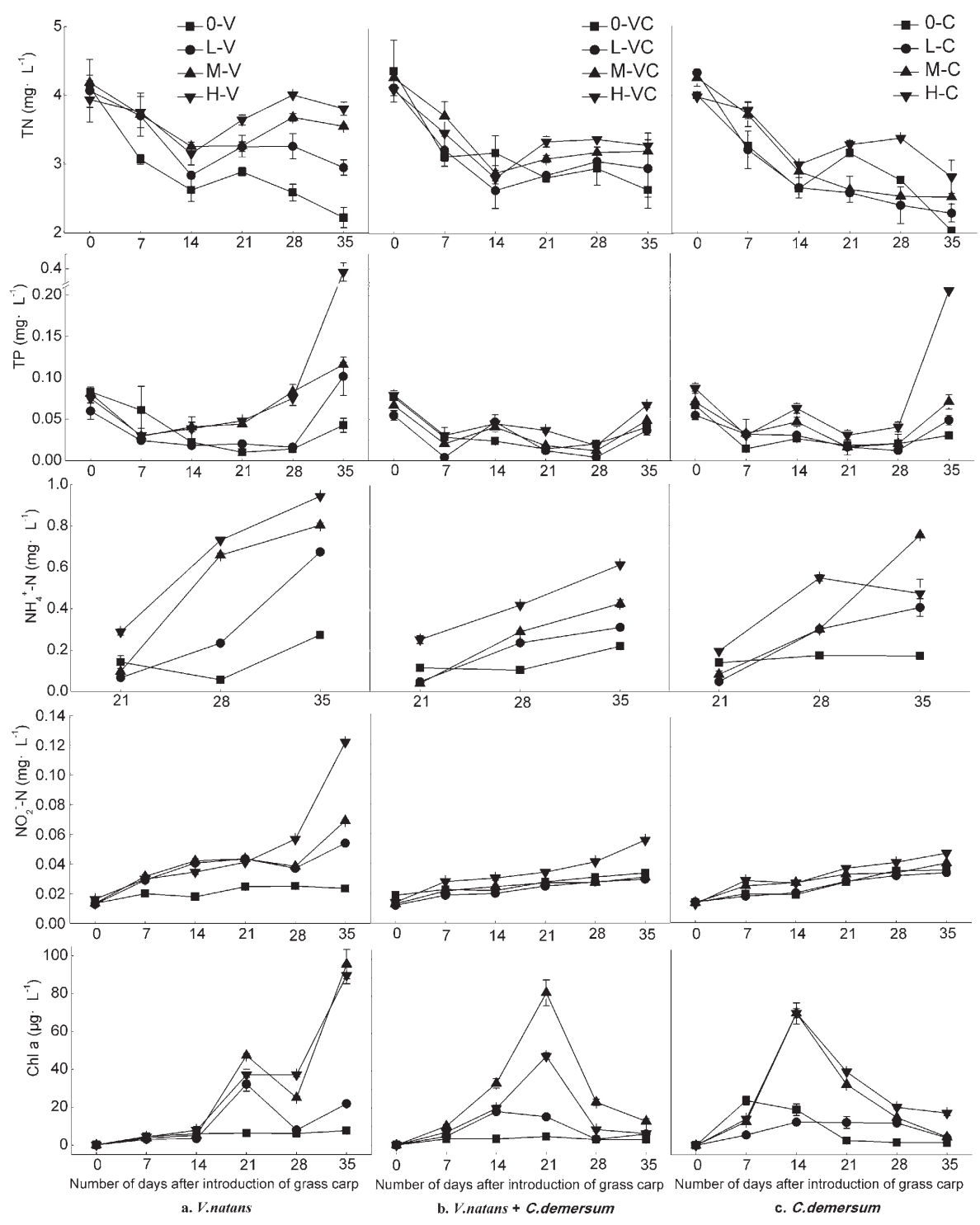

Fig. 3. Changes of TN, TP, $\mathrm{NH}_{4}^{+}-\mathrm{N}, \mathrm{NO}_{2}^{-}-\mathrm{N}$, and chl a in EXCR for each composition of submerged macrophyts with different densities of grass carp. $0-\mathrm{V}, \mathrm{L}-\mathrm{V}, \mathrm{M}-\mathrm{V}$, and $\mathrm{H}-\mathrm{V}$ represent $V$. natans only, low carp density $+V$. natans, medium carp density $+V$. natans, and high carp density $+V$. natans, respectively. 0 - VC, L-VC, M-VC, and $\mathrm{H}-\mathrm{VC}$ represent $V$. natans $+C$. demersum only, low carp density $+V$. natans $+C$. demersum, medium carp density $+V$. natans $+C$. demersum, and high carp density $+V$. natans $+C$. demersum, respectively. 0-C, L-C, M-C, and H-C represent $C$. demersum only, low carp density $+C$. demersum, medium carp density $+C$. demersum, and high carp density $+C$. demersum, respectively. 
For each composition of submerged macrophytes with different densities of grass carp, in Fig. 3a) TN and TP concentrations of L-V (low carp density $+V$. natans) were lower than those of $\mathrm{M}-\mathrm{V}$ (medium carp density + $V$. natans) and $\mathrm{H}-\mathrm{V}$ (high carp density $+V$. natans) from day 7 to day 35. The $\mathrm{NH}_{4}^{+}-\mathrm{N}$ and chl a concentrations of $\mathrm{M}-\mathrm{V}$ (medium carp density $+V$. natans) and $\mathrm{H}-\mathrm{V}$ (high carp density $+V$. natans) were higher than those of L-V (low carp density $+V$. natans) from day 21 to day 35. Although the values of $\mathrm{NO}_{2}^{-}-\mathrm{N}$ increased continuously, the differences between L-V (low carp density $+V$. natans) and $\mathrm{M}-\mathrm{V}$ (medium carp density $+V$. natans) and $\mathrm{H}-\mathrm{V}$ (high carp density $+V$. natans) were not significant $(\mathrm{p}<0.05)$. In Fig. $3 b)$, TN and chl a concentrations of L-VC (low carp density $+V$. natans +
C. demersum) were always lower than those of M-VC (medium carp density $+V$. natans $+C$. demersum) and $\mathrm{H}-\mathrm{VC}$ (high carp density $+V$. natans $+C$. demersum). Concentrations of $\mathrm{TP}, \mathrm{NH}_{4}^{+}-\mathrm{N}$, and $\mathrm{NO}_{2}^{-}-\mathrm{N}$ showed generally similar trends to those in Fig. 3a). In Fig. 3c), TN concentrations of L-C (low carp density $+C$. demersum) were lower than those of M-C (medium carp density $+C$. demersum) and $\mathrm{H}-\mathrm{C}$ (high carp density $+C$. demersum) from day 7 to day 35 . The trends of $\mathrm{TP}, \mathrm{NH}_{4}^{+}-\mathrm{N}, \mathrm{NO}_{2}^{-}-\mathrm{N}$, and chl a were generally similar to those in Fig. 3b). Water qualities without grass carp were better than those with fish for all macrophytic compositions. Hence, for all submerged macrophytes, the water quality was highest with the lowest stocking density of grass carp.

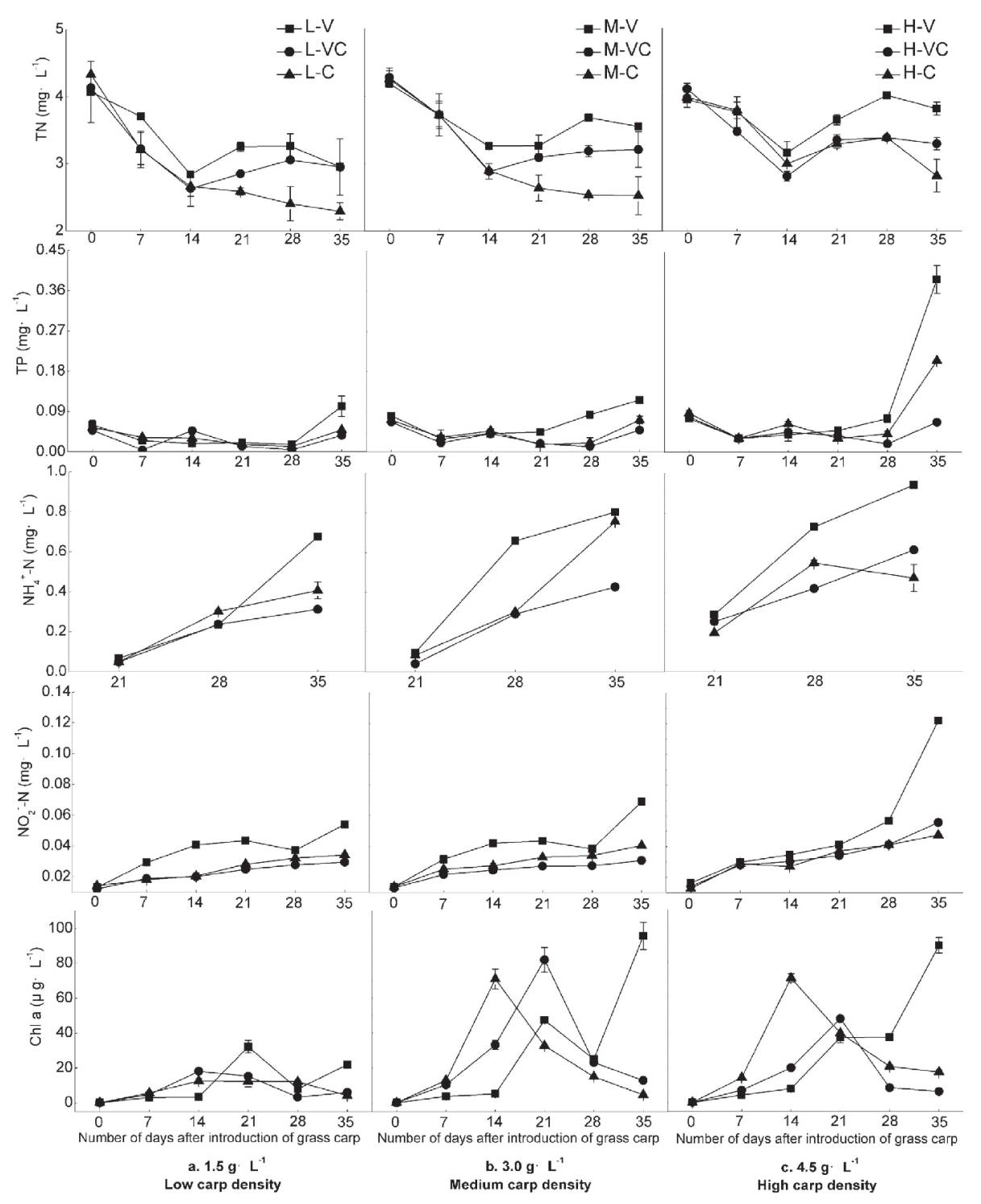

Fig. 4. Changes of TN, TP, $\mathrm{NH}_{4}^{+}-\mathrm{N}, \mathrm{NO}_{2}^{-}-\mathrm{N}$, and chl a in EXCR for the same density of grass carp with different kinds of submerged macrophytes. $0-\mathrm{V}, \mathrm{L}-\mathrm{V}, \mathrm{M}-\mathrm{V}$, and $\mathrm{H}-\mathrm{V}$ represent $V$. natans only, low carp density $+V$. natans, medium carp density $+V$. natans, and high carp density $+V$. natans, respectively. 0-VC, L-VC, M-VC, and $\mathrm{H}-\mathrm{VC}$ represent $V$. natans $+C$. demersum only, low carp density $+V$. natans $+C$. demersum, medium carp density $+V$. natans $+C$. demersum, and high carp density $+V$. natans $+C$. demersum, respectively. 0-C, L-C, M-C, and H-C represent $C$. demersum only, low carp density $+C$. demersum, medium carp density $+C$. demersum, and high carp density $+C$. demersum, respectively. 
For the same density of grass carp with different species of submerged macrophytes, Fig. 4a) shows that TN concentrations of L-VC (low carp density $+V$. natans $+C$. demersum) and L-C (Low carp density $+C$. demersum) were lower than those of L-V (Low carp density $+V$. natans) from day 7 to day 35. TP concentration of L-V (low carp density $+V$. natans) was higher than that of $\mathrm{L}-\mathrm{VC}$ (low carp density $+V$. natans $+C$. demersum) and L-C (low carp density $+C$. demersum) from day 21 to day 35. Concentrations of $\mathrm{NO}_{2}^{-}-\mathrm{N}$ increased during 35 days and the $\mathrm{NO}_{2}^{-}-\mathrm{N}$ concentration of $\mathrm{L}-\mathrm{V}$ (low carp density $+V$. natans) was always greater than that of L-VC (low carp density $+V$. natans $+C$. demersum) and L-C (low carp density $+C$. demersum). In Fig. 4b), concentrations of TN, TP, and $\mathrm{NO}_{2}^{-}-\mathrm{N}$ show generally similar trends to Fig. 4a). The $\mathrm{NH}_{4}^{+}-\mathrm{N}$ values of $\mathrm{M}-\mathrm{V}$ (medium carp density $+V$. natans) was consistently the highest. In Fig. 4c), TN values of $\mathrm{H}-\mathrm{V}$ (high carp density $+V$. natans) were higher than those of H-VC (high carp density $+V$. natans $+C$. demersum) and $\mathrm{H}-\mathrm{C}$ (high carp density $+C$. demersum) from day 7 to day 35. The trends of $\mathrm{TP}, \mathrm{NH}_{4}^{+}-\mathrm{N}$, and $\mathrm{NO}_{2}^{-}-\mathrm{N}$ were generally similar to those in Fig. 4b). In conclusion, for all three carp densities, water quality in the $V$. natans tanks was the worst.

\section{Effects of Excretion Plus Herbivory on Water Quality}

$V$. natans, when present in tanks without $C$. demersum, was totally consumed by grass carp 3 to 5 days following fish introduction. We therefore excluded this group from analysis, considering it to show no resistance to long-term carp feeding.

For each macrophytic composition with differing densities of grass carp, Fig. 5a) shows that $\mathrm{TN}$ and $\mathrm{NH}_{4}^{+}-\mathrm{N}$ concentrations of L-VC (low carp density $+V$. natans $+C$. demersum) and $\mathrm{M}-\mathrm{VC}$ (medium carp density $+V$. natans $+C$. demersum) were lower than those of H-VC (high carp density $+V$. natans $+C$. demersum) from day 0 to day 28. The TP concentrations of L-VC (low carp density $+V$. natans $+C$. demersum) were lower than those of M-VC (medium carp density $+V$. natans $+C$. demersum) and $\mathrm{H}-\mathrm{VC}$ (high carp density $+V$. natans $+C$. demersum) from day 14 to day 28. The $\mathrm{NO}_{2}^{-}-\mathrm{N}$ and chl a of L-VC (low carp density $+V$. natans $+C$. demersum) were much lower than $\mathrm{M}-\mathrm{VC}$ (medium carp density $+V$. natans $+C$. demersum) and $\mathrm{H}-\mathrm{VC}$ (high carp density $+V$. natans $+C$. demersum) from day 14 to day $28(\mathrm{p}<0.05)$. In Fig. $5 \mathrm{~b})$, $\mathrm{TN}, \mathrm{TP}$, and chl a concentrations of L-C (low carp density $+C$. demersum) were lower than those of $\mathrm{M}-\mathrm{C}$ (medium carp density $+C$. demersum) and H-C (high carp density $+C$. demersum) from day 7 to day $28 . \mathrm{NH}_{4}^{+}-\mathrm{N}$ of $\mathrm{H}-\mathrm{C}$ (high carp density $+C$. demersum) was greater than L-C (low carp density $+C$. demersum) and $\mathrm{M}-\mathrm{C}$ (medium carp density $+C$. demersum) from day 7 to day 28 . $\mathrm{NO}_{2}^{-}-\mathrm{N}$ concentrations showed generally similar trends to Fig. 5a). Consequently, we can conclude that with increasing densities of grass carp, water quality deteriorated rapidly for each species of submerged macrophyte.
When comparing the same density of grass carp with different species of submerged macrophytes, TN, TP, and chl a concentrations of of L-VC (low carp density $+V$. natans $+C$. demersum) were usually higher than those of L-C (low carp density $+C$. demersum) (Fig. $6 a)$. However, the difference between $\mathrm{NO}_{2}^{-}-\mathrm{N}$ of $\mathrm{L}-\mathrm{VC}$ (low carp density $+V$. natans $+C$. demersum) and L-C (low carp density $+C$. demersum) was not significant ( $>0.05$ ). In Fig. 6b), the concentrations of TP and chl a of M-C (medium carp density $+C$. demersum) were much

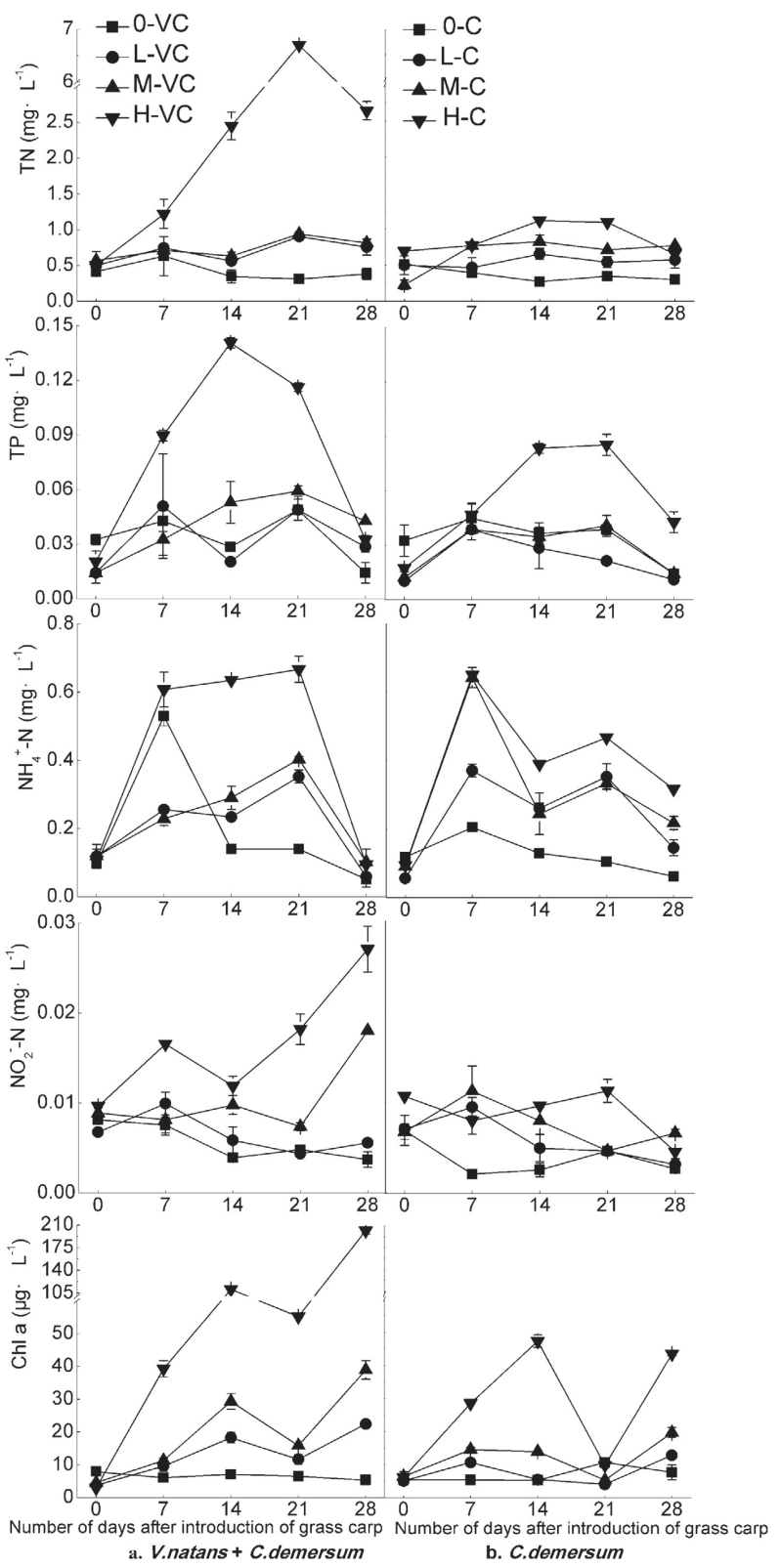

Fig. 5. Changes of TN, TP, $\mathrm{NH}_{4}^{+}-\mathrm{N}, \mathrm{NO}_{2}^{-}-\mathrm{N}$, and chl a in HERBEXCR for each macrophytic composition with differing densities of grass carp. 0-VC, L-VC, M-VC, and $\mathrm{H}-\mathrm{VC}$ represent $V$. natans $+C$. demersum only, low carp density $+V$. natans $+C$. demersum, medium carp density $+V$. natans $+C$. demersum, and high carp density $+V$. natans $+C$. demersum, respectively. $0-C, \mathrm{~L}-\mathrm{C}, \mathrm{M}-\mathrm{C}$, and $\mathrm{H}-\mathrm{C}$ represent $C$. demersum only, low carp density $+C$. demersum, medium carp density $+C$. demersum, and high carp density $+C$. demersum, respectively. 
lower than those of M-VC (medium carp density $+V$. natans $+C$. demersum) from day 14 to day $28(\mathrm{p}<0.05)$. The $\mathrm{NO}_{2}^{-}-\mathrm{N}$ concentrations of M-C (medium carp density $+C$. demersum) were lower than those of M-VC (medium carp density $+V$. natans $+C$. demersum) from day 10 to day 28. In Fig. 6c), the $\mathrm{TN}, \mathrm{TP}, \mathrm{NO}_{2}^{-}-\mathrm{N}$, and chl a concentrations of $\mathrm{H}-\mathrm{C}$ (high carp density $+C$. demersum) was mainly lower than those of H-VC (high carp density $+V$. natans $+C$. demersum) during most days. Hence, we conclude that water quality in tanks with only $C$. demersum was better than other macrophytic compositions.

Comparing the Effects of Excrement and Herbivory of Grass Carp on Water Quality

The increasing rates of TN in HERB-EXCR were less than those in EXCR except for in $\mathrm{H}-\mathrm{VC}$. This was not the same as TP. However, for $\mathrm{NH}_{4}^{+}-\mathrm{N}, \mathrm{NO}_{2}^{-}-\mathrm{N}$, and chl a, the

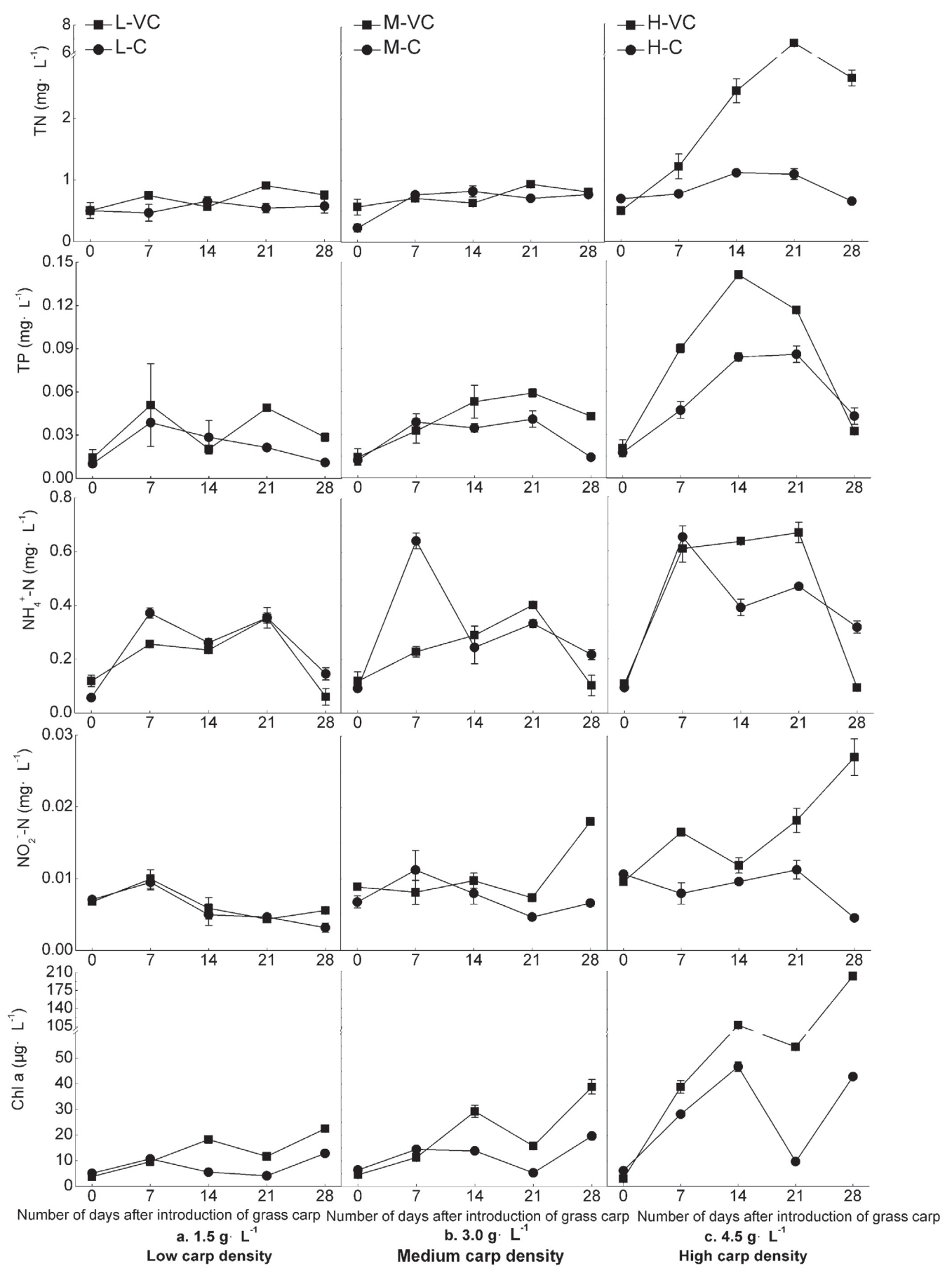

Fig. 6. Changes of TN, TP, $\mathrm{NH}_{4}^{+}-\mathrm{N}, \mathrm{NO}_{2}^{-}-\mathrm{N}$, and chl a in HERB-EXCR for the same density of grass carp with different kinds of submerged macrophytes. L-VC and L-C represent low carp density $+V$. natans $+C$. demersum and low carp density $+C$. demersum, respectively. M-VC and M-C represent medium carp density $+V$. natans $+C$. demersum and medium carp density $+C$. demersum, respectively. H-VC and $\mathrm{H}-\mathrm{C}$ represent high carp density $+V$. natans $+C$. demersum and high carp density $+C$. demersum, respectively. 
Table 3. The increasing rates (\%) of TN, TP, $\mathrm{NH}_{4}^{+}-\mathrm{N}, \mathrm{NO}_{2}^{-}-\mathrm{N}$, and chl a in EXCR and HERB-EXCR.

\begin{tabular}{|c|c|c|c|c|c|c|c|c|c|c|c|}
\hline \multirow{2}{*}{\multicolumn{2}{|c|}{ EXCR }} & \multicolumn{2}{|c|}{ TN (\%) } & \multicolumn{2}{|c|}{ ТР (\%) } & \multicolumn{2}{|c|}{$\mathrm{NH}_{4}^{+}-\mathrm{N}(\%)$} & \multicolumn{2}{|c|}{$\mathrm{NO}_{2}^{-}-\mathrm{N}(\%)$} & \multicolumn{2}{|c|}{ Chl a $(\%)$} \\
\hline & & HERB- & EXCR & HERB- & FXCR & HERB- & FXCR & HERB- & EXCR & HERB- & \\
\hline \multirow{3}{*}{ Low density } & L-V & -19.6 & & -3.3 & & 242.6 & & 144.3 & & -26.7 & \\
\hline & L-VC & -24.6 & -31.7 & -53.6 & -49.0 & 58.3 & 177.8 & 45.0 & 660.3 & -56.5 & 1866.3 \\
\hline & L-C & -36.0 & -49.0 & -39.6 & -70.5 & 106.1 & 248.9 & 63.7 & 512.8 & -50.9 & 880.4 \\
\hline \multirow{3}{*}{$\begin{array}{l}\text { Medium } \\
\text { density }\end{array}$} & $\mathrm{M}-\mathrm{V}$ & -10.0 & & 60.7 & & 308.2 & & 175.9 & & -17.2 & \\
\hline & $\mathrm{M}-\mathrm{VC}$ & -18.5 & -27.9 & -37.5 & -29.5 & 117.0 & 234.5 & 54.0 & 1526.9 & -53.8 & 3043.2 \\
\hline & M-C & -31.1 & -31.4 & -14.9 & -58.4 & 283.6 & 313.7 & 91.8 & 802.4 & -42.5 & 1477.2 \\
\hline \multirow{3}{*}{ High density } & $\mathrm{H}-\mathrm{V}$ & -3.9 & & 246.9 & & 379.1 & & 292.3 & & 17.7 & \\
\hline & $\mathrm{H}-\mathrm{VC}$ & -15.9 & 229.9 & -11.2 & 22.9 & 212.6 & 485.9 & 134.8 & 2610.1 & -29.5 & 14067.4 \\
\hline & $\mathrm{H}-\mathrm{C}$ & -19.1 & -20.2 & 99.8 & -7.1 & 140.2 & 465.2 & 120.8 & 957.6 & -33.8 & 3650.5 \\
\hline
\end{tabular}

increasing rates in HERB-EXCR were at least two times more than in EXCR, except for $\mathrm{NH}_{4}^{+}-\mathrm{N}$ of $\mathrm{M}-\mathrm{C}$ (medium carp density $+C$. demersum) (Table 3 ). Therefore, we can conclude that when grass carp are feeding on submerged macrophytes, water quality deteriorated in terms of $\mathrm{NH}_{4}^{+}-\mathrm{N}, \mathrm{NO}_{2}^{-}-\mathrm{N}$, and chl a, but not in terms of TN and TP.

\section{Effects on Zooplankton}

In EXCR, the ES of protozoa was less than zero for $V$. natans, indicating that the excretion from grass carp did not increase the biomass of protozoa. The ES of rotifers and total zooplankton was more than zero at the densities of 0.15 and $0.45 \mathrm{~g} \cdot \mathrm{L}^{-1}$. At $0.15 \mathrm{~g} \cdot \mathrm{L}^{-1}$, the excretion from grass carp had a positive effect on cladocerans biomass, and the effect on copepods biomass was negative (Fig. 7). Regardless of grass carp density, ES of protozoa, cladocerans, copepods, and total zooplankton were less than zero, showing that the excretion from grass carp did not stimulate their growth in the combined $V$. natans and $C$. demersum environment. However, the effect on rotifers was the opposite (Fig. 7). The ES of excretion on rotifers, cladocerans, and total zooplankton increased as the density of grass carp increased in C. demersum, a trend that was not reflected in protozoa and copepods. The ES of protozoa reached a maximum at a grass carp density of $0.45 \mathrm{~g} \cdot \mathrm{L}^{-1}$ in $C$. demersum (Fig. 7).

In HERB-EXCR, for $V$. natans and $C$. demersum together, the ES of protozoa and total zooplankton at density of $0.45 \mathrm{~g} \cdot \mathrm{L}^{-1}$ were greater than those at $0.15 \mathrm{~g} \cdot \mathrm{L}^{-1}$, and both were greater than zero. The ES of rotifers was positive and decreased with increasing grass carp density. The ES of cladocerans and copepods increased and reached a maximum at $0.45 \mathrm{~g} \cdot \mathrm{L}^{-1}$ (Fig. 7). For C. demersum, the ES of protozoa, copepods, and total zooplankton were greater than zero and did not show a clear trend with changing carp densities. The ES of rotifers was more than zero and increased with increasing carp density. At $0.15 \mathrm{~g} \cdot \mathrm{L}^{-1}$, the ES of cladocerans was zero and it decreased when carp density increased (Fig. 7).
We compared the effects on zooplankton in EXCR with those in HERB-EXCR and drew the following conclusion: the effects on protozoa, copepods, and total zooplankton in HERB-EXCR were greater than those in EXCR, showing that herbivory by and excretion from grass carp can significantly enhance zooplankton biomass. However, for rotifers and cladocerans, HERB-EXCR showed no obvious difference in biomass to that of EXCR (Fig. 7).

\section{Discussion}

The results from our experiment indicated that whether through excretion and herbivory, or solely the former, grass carp, as a typical herbivorous fish, has profound effects on water quality and zooplankton biomass. The impacts of grass carp in HERB-EXCR were much greater than in EXCR. We discuss the potential mechanisms behind these consequences in the following ways.

\section{Effects on Water Quality}

For the same composition of submerged macrophytes in both EXCR and HERB-EXCR, when the density of grass carp was lower, the water quality was better. Grass carp had a poor utilization of plants and a great mass of the nutrients consumed in the form of aquatic macrophytes that were released back into water via excretion [23], which can bring unwanted changes to water conditions. And Pípalová (2006) reported that grass carp at stocking densities of $450 \mathrm{~kg} \cdot \mathrm{ha}^{-1}$ can increase higher concentrations of nutrients in water than stocking densities of 150 $\mathrm{kg} \cdot \mathrm{ha}^{-1}[24]$. So a greater stocking density of fish will result in the release of higher levels of excretion, which will accelerate deterioration in water quality.

A number of studies have reported that compared to $V$. natans, $C$. demersum has a better capacity to clean water and improve its quality [25-28], and Sun et al. (2015) demonstrated that grass carp prefer $V$. natans to 


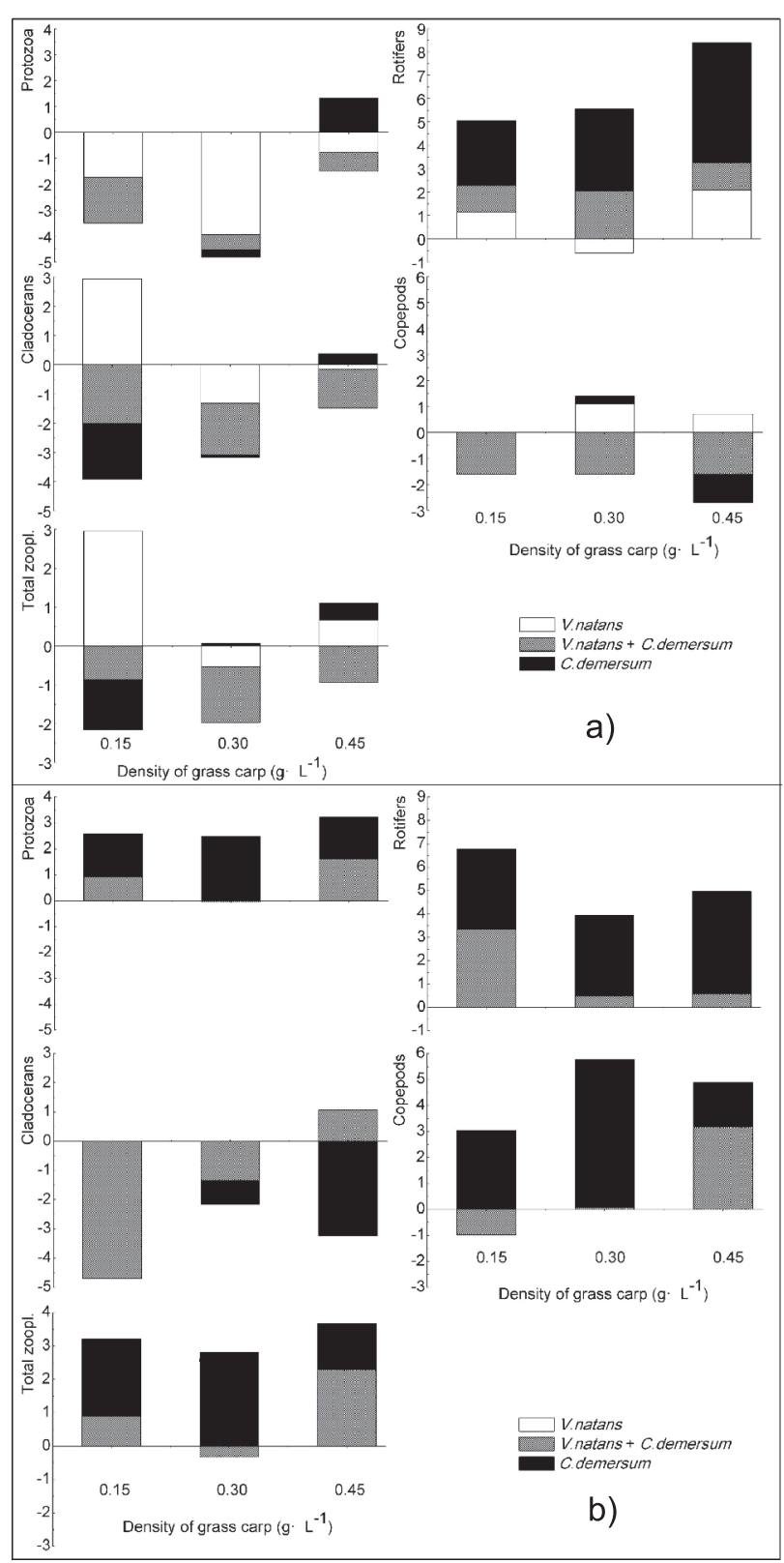

Fig. 7. Effect of size of grass carp on zooplankton. a) in EXCR, b) in HERB-EXCR. Total zoopl. is abbreviated as total zooplankton.

C. demersum in the same freshwater environment [29]. Therefore, in EXCR water quality in $V$. natans tanks was worse than in others, and in HERB-EXCR the water quality in $C$. demersum tanks was better than that in $V$. natans $+C$. demersum tanks.

When comparing effects of EXCR and HERB-EXCR on water quality, we speculated that the concentration of $\mathrm{NH}_{4}^{+}-\mathrm{N}, \mathrm{NO}_{2}^{-}-\mathrm{N}$, and chl a significantly increased in HERB-EXCR. This indicated that grass carp herbivory on submerged macrophytes could be the central mechanism accounting for the changes in water quality.

Submerged macrophytes, as the vital primary producers in aquatic ecosystems, play an important role in improving water quality [30-32]. However, reduction in the biomass of submerged macrophytes resulting from grass carp feeding can weaken the capability of water purification by plants. Hence, the worst water quality observed in HERBEXCR was due to herbivory by fish.

During grass carp feeding, excretion (consisting of approximately $80 \%$ ammonia, a little carbamide, and some undisgestive plants) discharged by fish into water increased the concentrations of $\mathrm{NH}_{4}^{+}-\mathrm{N}, \mathrm{NO}_{2}^{-}-\mathrm{N}, \mathrm{TN}$, and TP $[16,33]$. In our study, grass carp seemed to enhance the concentration of $\mathrm{NH}_{4}^{+}-\mathrm{N}$ and $\mathrm{NO}_{2}^{-}-\mathrm{N}$ through excretion. Nonetheless, the concentrations of TN and TP in most tanks decreased during the experimental period. This may be because phytoplankton absorbs $\mathrm{N}$ (expect $\mathrm{NH}_{4}^{+}-\mathrm{N}$ and $\mathrm{NO}_{2}^{-}-\mathrm{N}$ ) and $\mathrm{P}$ nutrients from water. Therefore, concentrations of chl a, usually representative of phytoplankton biomass, remain high in HERB-EXCR. In contrast, the low concentrations of chl a in EXCR may be a result of submerged macrophytes inhibiting the growth of phytoplankton through competition for light, nutrients, and/or allelopathic effects [34-36].

\section{Effects on Zooplankton}

The influences of grass carp on zooplankton tend to be indirect, owing to the promotion of zooplankton growth by grass carp through consumption of macrophytes and increasing rates of nutrition [24, 37]. This matches with our result that the effects on protozoa, copepods, and total zooplankton in HERB-EXCR were greater than that in EXCR, yet disagrees with our findings on rotifers and cladocerans. This may be because between EXCR and HERB-EXCR there were different groups of phytoplankton that affected the growth of rotifers and cladocerans $[16,38]$.

Further studies should specify and identify the types of phytoplankton and zooplankton influenced by grass carp, and determine the corresponding relationships in detail.

\section{Conclusions}

In this study we determined that high stocking densities of grass carp can result in a decrease in water quality through excretion or herbivory. Water qualities obtained with $C$. demersum were better than those with $V$. natans. As both grass carp and submerged macrophytes have important roles in the ecological restoration of water bodies, and with grass carp herbivory on submerged macrophytes playing a vital role in influencing water quality and zooplankton communities, it is better to select a low stocking density of grass carp to control the growth of submerged macrophytes and where possible to choose C. demersum as a suitable species to be tackled.

\section{Acknowledgements}

This study was supported by grants from the National Science and Technology Support Program of the $12^{\text {th }}$ FiveYear Plan, China (No. 2012BAJ21B03-004), the National 
Natural Science Foundation of China (51178452), the Major Science and Technology Program for Water Pollution Control and Treatment of China's $12^{\text {th }}$ FiveYear Plan (No. 2012ZX07101007-005), and the Hubei Province Science Foundation for Youth (2014CFB282). The authors thank Profs. Yongyuan Zhang and Baoyuan Liu; Drs. Yafen Wang, Biyun Liu, Enrong Xiao, Dong $\mathrm{Xu}$, and Junmei $\mathrm{Wu}$; and Ms. Liping Zhang for the experimental assistance and paper preparation (Institute of Hydrobiology, Chinese Academy of Sciences).

\section{References}

1. SØNDERGAARD M., JOHANSSON L.S., LAURIDSEN T.L., JØRGENSE T.B., LIBORIUSSEN L., JEPPESEN E. Submerged macrophytes as indicators of the ecological quality of lakes. Freshwater Biol. 55 (4), 893, 2010.

2. BLINDOW I., HARGEBY A., MEYERCORDT J., SCHUBERT H. Primary production in two shallow lakes with contrasting plant form dominance: a paradox of enrichment? Limnol. Oceanogr. 51 (6), 2711, 2006.

3. DOMINGUES F.D., STARLING F.L.R.M., NOVA C.C., LOUREIRO B.R., SOUZA L.C., BRANCO C.W.C. The control of floating macrophytes by grass carp in net cages: experiments in two tropical hydroelectric reservoirs. Aquac. Res. 1, 2016.

4. MITCHELL A.J., KELLY A.M. The public sector role in the establishment of grass carp in the United States. Fisheries. 31 (3), 113, 2006.

5. WELLS R.D.S., BANNON H.J., HICKS B.J. Control of macrophytes by grass carp (Ctenopharyngodon idella) in a Waikato drain, New Zealand. New Zeal. J. Mar. Fresh. 37, 85, 2003.

6. ZAJICEK P.W., WEIER T., HARDIN S., CASSANI J.R., MUDRAK V. A triploid grass carp risk analysis specific to Florida. J. Aquat. Plant Manage. 47, 15, 2009.

7. RICHARDSON R.J. Aquatic plant management and the impact of emerging herbicide resistance issues. Weed technology. 22, 11, 2008.

8. WOOD K.A., O〉HARE M.T., MCDONALD C., SEARLE K.R., DAUNT F., STILLMAN R.A. Herbivore regulation of plant abundance in aquatic ecosystems. Biol. Rev. 1, 2016.

9. GARNER A.B., KWAK T.J., MANUEL K.L., BARWICK D.H. High-density grass carp stocking effects on a reservoir invasive plant and water quality. J. Aquat. Plant Manage. 51, 27, 2013.

10. HOFSTRA D.E., CLAYTON J.S. Assessment of the efficacy of contained grass carp at removing the aquatic weed hornwort; Ministry Primary Industries: New Zealand, pp. 1-20, 2012.

11. STEPHEN D., BALAYLAD.M., BÉCARES E., COLLINGS S.E., FERNÁNDEZ-ALÁEZ C., FERNÁNDEZ-ALÁEZ M., FERRIOL C., GARCÍA P., GOMÁ J., GYLLST ÖM M., HANSSON L.A., HIETALA J., KAIRESALO T., MIRACLE M. R., ROMO S., RUEDA J., STÅHL-DELBANCO A., SVENSSON M., VAKKILAINEN K., VALENTÍN M., VAN DE BUND W. J., VAN DONK E., VICENTE E., VILLENA M. J., MOSS B. Continental-scale patterns of nutrient and fish effects on shallow lakes: introduction to a pan-European mesocosm experiment. Freshwater Biol. 49, 1517, 2004.

12. HIETALA J., VAKKILAINEN K., KAIRESALO T. Community resistance and change to nutrient enrichment and fish manipulation in a vegetated lake littoral. Freshwater Biol. 49, 1525, 2004.

13. VAN DE BUND W.J., VAN DONK E. Effects of fish and nutrient additions on food-web stability in a charophytedominated lake. Freshwater Biol. 49, 1565, 2004.

14. MENEZES R.F., ATTAYDE J.L., VASCONCELOS F.R. Effects of omnivorous filter-feeding fish and nutrient enrichment on the plankton community and water transparency of a tropical reservoir. Freshwater Biol. 55, 767, 2010.

15. HAVENS K.E., ELIA A.C., TATICCHI M.I., FULTON R.S. Zooplankton- phytoplankton relationships in shallow subtropical versus temperate lakes Apopka (Florida, USA) and Trasimeno (Umbria, Italy). Hydrobiologia. 628, 165, 2009.

16. KRUPSKA J., PELECHATY M., PUKACZ A., OSSOWSK P. Effects of grass carp introduction on macrophyte communities in a shallow lake. Oceanol. Hydrobiol. St. 41 (1), 35, 2012.

17. STATE EPA OF CHINA (ED.). Monitoring and determination methods for water and wastewater, 4th ed. China Environmental Science Press, Beijing, 2002 [In Chinese].

18. SHIN-ICHIRO S.M., USIO N., TAKAMURA N., WASHITANI I. Contrasting impacts of invasive engineers on freshwater ecosystems: an experiment and meta-analysis. Oecologia. 158,676, 2009.

19. HANSSON L.A., GYLLSTRÖM M., STAHL-DELBANCO A., SVENSSON M. Responses to fish predation and nutrients by plankton at different levels of taxonomic resolution. Freshwater Biol. 49, 1540, 2004.

20. JAKOBSEN T.S., HANSEN P.B., JEPPESEN E., GRØNKJAER P., SØNDERGAARD M. Impact of threespined stickleback Gasterosteus aculeatus on zooplankton and chl a in shallow, eutrophic, brackish lakes. Mar. EcolProg. Ser. 262, 279, 2003.

21. GLAHOLT S.P, VANNI M.J. Ecological responses to simulated benthic-derived nutrient subsidies mediated by omnivorous fish. Freshwater Biol. 50, 1869, 2005.

22. ATTAYDE J.L., HANSSON L.A. The relative importence of fish predation and excretion effects on planktonic communities. Limnol. Oceanogr. 46 (5), 1003, 2001.

23. GÎLCÃ V. Research concerning the feed digestibility and the digestive utilization coefficient in grass carp (Ctenopharingodon idella). AACL. Bioflux. 3 (5), 378, 2010.

24. PÍPALOÁ I. A review of grass carp use for aquatic weed control and its impact on water bodies. J. Aquat. Plant Manage. 44, 7, 2006

25. WANG C., ZHENG S.S., WANG P.F., QIAN J. Effects of vegetations on the removal of contaminants in aquatic environments: A review. J. Hydrodyn. 26 (4), 498, 2014

26. GAO J.Q., XIONG Z.T., ZHANG J.D., ZHANG W.H., MBA F.O. Phosphorus removal from water of eutrophic Lake Donghu by five submerged macrophytes. Desalination. 242, 193, 2009.

27. SRIVASTAVA J., GUPTA A., CHANDRA H. Managing water quality with aquatic macrophytes. Rev. Environ. Sci. Biotechnol. 7, 261, 2008.

28. TRACY M., MONTANTA J.M., ALLENSON T.E., HOUGH R.A. Long-term responses of aquatic macrophyte diversity and community structure to variation in nitrogen loading. Aquat. Bot. 77, 43, 2003.

29. SUN J., HE F., ZHANG Y., LIU B.Y., ZHOU Q.H., WU Z.B. The feeding behavior of grass carp (Ctenopharyngodon idellus) on different types of submerged plants. Acta Hydrobiologica Sinica. 5 (39), 997, 2015 [In Chinese]. 
30. DAI Y.R., JIA C.R., LIANG W., HU S.H., WU Z.B. Effects of the submerged macrophyte Ceratophyllum demersum L. on restoration of a eutrophic waterbody and its optimal coverage. Ecol. Eng. 40, 113, 2012.

31. PAN G., YANG B., WANG D., CHEN H., TIAN B.H., ZHANG M.H., YUAN X.Z., CHEN J. In-lake algal bloom removal and submerged vegetation restoration using modified local soils. Ecol. Eng. 37, 302, 2011.

32. HUSSNER A., STIERS I., VERHOFSTAD M.J.J.M., BAKKER E.S., GRUTTERS B.M.C., HAURY J., VAN VALKENBURG J.L.C.H., BRUNDU G., NEWMAN J., CLAYTON J.S., ANDERSON L.W.J., HOFSTRA D. Management and control methods of invasive alien freshwater aquatic plants: A review. Aquat. Bot. 136, 113, 2017.

33. WEYL P.S.R., MARTIN G.D. Have grass carp driven declines in macrophyte occurrence and diversity in the Vaal River, South Africa? Afr. J. Aquat. Sci. 41 (2), 241, 2016.

34. GETTE-BOUVAROT M., MERMILLOD-BLONDIN F., LEMOINE D., DELOLME C., DANJEAN M., ETIENNE L., VOLATIER L. The potential control of benthic biofilm growth by macrophytes-A mesocosm approach. Ecol. Eng. 75, 178, 2015.

35. ZHANG S. H., GUO L., CAO J.Y., CHANG J.J. Allelopathic activities of three emergent macrophytes on several monospecific cyanobacterial species and natural phytoplankton assemblages. Pol. J. Environ. Stud. 24 (1), 397, 2015.

36. WANG H.Q., LIANG F., ZHANG L.Y. Composition and anti-cyanobacterial activity of essential oils from six different submerged macrophytes. Pol. J. Environ. Stud. 24 (1), 333, 2015.

37. VRANOVSKY M. Zooplankton of a Danube side arm under regulated ichthyocoenosis conditions. International Vereinigung fuer Theoretische und Angewandte Limnoligie. 24, 2507, 1991.

38. ZHANG S.Y., ZHOU Q.H., XU D., HE F, CHENG S.P., LIANG W., DU C., WU Z.B. Vertical-flow constructed wetlands applied in a recirculating aquaculture system for channel catfish culture: effects on water quality and zooplankton. Pol. J. Environ. Stud. 19 (5), 1069, 2010. 